\title{
Satisfaction of the Service Provider with the Organization of the Timely Cervical Cancer Detection Program
}

\author{
Gutiérrez-Enríquez Sandra Olimpia ${ }^{1}$, Terán-Figueroa Yolanda1*, Gaytán-Hernández Darío', \\ Díaz-Oviedo Aracely' ${ }^{1}$, Zúñiga-Martínez Ma. de Lourdes², Hernández-Nava Nereyda², \\ Cruz Ortíz Maribel1, Pérez Rodríguez María del Carmen1, Ramírez-Ramírez Rocío1
}

\author{
${ }^{1}$ Faculty of Nursing and Nutrition, Autonomous University of San Luis Potosi, San Luis Potosi, Mexico \\ ${ }^{2}$ Academic Coordination Altiplano Region, Autonomous University of San Luis Potosi, San Luis Potosi, Mexico \\ Email: `yolandat@uaslp.mx
}

How to cite this paper: Olimpia, G.-E.S., Yolanda, T.-F., Darío, G.-H., Aracely, D.-O., de Lourdes, Z.-M.Ma., Nereyda, H.-N., Maribel, C.O., del Carmen, P.R.M. and Rocío, R.-R. (2017) Satisfaction of the Service Provider with the Organization of the Timely Cervical Cancer Detection Program. Health, 9, 289-298.

https://doi.org/10.4236/health.2017.92020

Received: January 24, 2017

Accepted: February 14, 2017

Published: February 17, 2017

Copyright $\odot 2017$ by authors and Scientific Research Publishing Inc. This work is licensed under the Creative Commons Attribution International License (CC BY 4.0).

http://creativecommons.org/licenses/by/4.0/

\begin{abstract}
Cervical cancer is a priority health problem in Mexico. The objective of this work was to know the degree of satisfaction of the service provider with the organization of the program of Timely Detection of Cervical Cancer, specifically in taking of the cervical cytology. The study design was observational, transversal and prospective conducted from January to May 2015 in Jurisdiction 1 of the Health Services of San Luis Potosí, Mexico, in 20 health centers. Participants were 87 service providers whose function is to take cervical cytology (Pap smears). A 32-question questionnaire was applied, with Likert scale with 5 levels of response: 1 (dissatisfied), 2 (little satisfied), 3 (indifferent), 4 (satisfied) and 5 (very satisfied). The score range was 32 points (minimum job satisfaction) up to 160 points (Maximum job satisfaction). We analyzed 2 dimensions: 1) intrinsic factors that have to do with motivation and professional recognition, and 2) extrinsic factors related to infrastructure, materials, remuneration and labor policies. Each factor consisted of four categories. Descriptive statistics and linear correlation of Pearson were applied for the analysis of data. Participants signed an informed consent letter. Of 4 categories, in the intrinsic dimension, the one with the highest percentage of satisfaction was "delegation of activities" with $28.8 \%$. In the extrinsic dimension, the category with the highest percentage of satisfaction was "infrastructure and materials" with 49.4\%; while satisfaction increase in intrinsic dimensions also does in extrinsic dimensions, such correlations are significant $(\mathrm{p}<$ $0.05)$, except between delegation of activities and remuneration $(r=0.074$ and $p=0.497$ ). The higher hierarchical level, the men, the bachelor academic level and older people showed the highest level of satisfaction.
\end{abstract}




\section{Keywords}

Job Satisfaction, Cervical Cancer, Health Providers

\section{Introduction}

Cervical cancer (CC) is the malignant neoplasia that usually arises in the region of the squamo-columnar junction of the cervical epithelium of the uterus and worldwide has a negative impact on the female population. Despite the existence of screening programs, women suffer and die from this disease [1]. In 2012 there were 5,280,000 new cases [2], affecting approximately six out of every 100,000 women; this represents approximately 275,000 deaths per year in developing countries, which corresponds $88 \%$ of the cases worldwide [3]. Mortality rates are 3 times higher in Latin America and the Caribbean than in North America, which reveals enormous inequalities in health [4]. One of the CC's research lines is the health systems, where quality management indicators such as evaluation are used, in this case, of the Cervical Cancer Screening Program.

The Specific Action Program 2007-2012 of CC in Mexico [5] indicates that the inefficiency of this is due in large part to environmental factors, like favorable conditions of work and infrastructure (extrinsic factors). These refer to the fact that workers like to perform their work in a pleasant environment, of independence and therefore, favoring the welfare and quality of their work. Here also influences the organizational culture of the company, where it is sought that the organizational and personal goals are compatible, and if this happens, the workers will perceive it in a positive way, thus promoting a higher degree of job satisfaction. They also influence salary compensation and promotion strategies [6].

It is thus that this work has as research line the satisfaction of the service provider that implements the Cervical Cancer Timely Detection program. Frederick Herzberg was taken as a theoretical reference, who in his theory of motivation and hygiene, also known as the two-factor theory, points out that satisfaction result of motivational factors and that the lack of them causes job dissatisfaction. His studies show that motivation in work environments stems from two sets of independent and specific factors: Intrinsic and extrinsic. Thus, intrinsic factors are related to the challenge to work, compatibility between personalities, job post and job opportunity. On the other hand, the extrinsic factors are the favorable conditions of work, the remuneration and the policies of the company [7]. In this way, the present study analyzes the satisfaction of the personnel with the infrastructure, inputs and the organization of the program of Timely Detection of Cervical Cancer, as well as the motivation of the employee towards his work.

\section{Methods}

\subsection{Data Source}

A quantitative, observational, cross-sectional and prospective study conducted 
in the period of January-May 2015 in Jurisdiction 1 of the Health Services of San Luis Potosí, Mexico, in 20 health centers. Were studied 87 people, which are the total number of staff whose function is to take cervical cytology (Pap smears).

To evaluate the level of satisfaction of the personnel participating in the Program for the Timely Detection of Cervical Cancera questionnaire was carried out. It consists of 32 questions; each one structured using a Likert scale, of 1 - 5 in the sense of lower to higher degree of satisfaction as follows: 1) (dissatisfied), 2) (little satisfied), 3) (indifferent), 4) (satisfied) and 5) (very satisfied). The score range of the entire questionnaire ranged from 32 (minimum work satisfaction) to 160 (maximum job satisfaction). The 2 factors explored were: extrinsic by categories (self-realization, professional recognition, delegation of activities and recognition of contributions to the program); and intrinsic categories (infrastructure and materials, remuneration, labor relations and policies of the institution). The survey was answered as an interview.

\subsection{Data Analysis}

Statistical analysis was performed through the SPSS version 18 program. Pearson's linear correlation was applied to the scores obtained in each of the intrinsic and extrinsic dimensions and a level of significance of 0.05. Applied the mean and standard deviation for determine the variables of the job satisfaction of the professionals in charge of cytology at each health center.

\subsection{Ethical Considerations}

The legal provisions on risk-free investigations promulgated by the General Health Law article 17 [8] were taken in to account. The present study complies with the principles of the Helsinki Declaration. Participants signed an informed consent letter. The present research was approved by the Ethics Committee of the Faculty of Nursing and Nutrition of the UASLP with the registration number CEIFE 2015-108.

\section{Results}

In relation to the age of the service provider, it was organized by age range of 19 to 29 years, 30 to 39 years, 40 to 49 years and 50 to 69 years, this for greater ease at the time of interpretation. The range with the highest percentage was from 19 to 29 years (36\%) and the lowest percentage was from 50 to 69 years (14\%). In relation to the sex of the service provider, $74 \%$ are women $26 \%$ men. The profession exercised by the provider is as follows: $56 \%$ are nurses, $24 \%$ are doctors and $20 \%$ are interns (nursing or medicine). On the other hand, the position of the service provider was $35 \%$ as a general nurse, $24 \%$ as a doctor, $14 \%$ in another position (interns and members of the brigade of the program for the timely detection of cervical cancer), $11 \%$ as auxiliary or nursing technicians and $5 \%$ as director or deputy director of the unit or health center. As for the academic level of the service provider, $72 \%$ have bachelor's degree, $20 \%$ are technical or auxiliary, $8 \%$ have a postgraduate degree and only $1 \%$ have a higher secondary level (bac- 
calaureate or technical) (Table 1).

The age of the service provider was organized for decades from 19 to 29 years, 30 to 39 years, 40 to 49 years, 50 to 59 years and 60 to 69 years. The range with the highest percentage of satisfaction was 50 to 59 years (44.4\% satisfied), followed by the range of 60 to 69 years (33.3\% highly satisfied), the range of 30 to 39 years (18.2\% satisfied), the range of 40 to 49 years (18.1\% satisfied), and the range of 19 to 29 years (6.5\% satisfied). In relation to the sex of the service provider, $74 \%$ are women and $26 \%$ are men. The men reported a higher degree of equivalent satisfaction than women $(21.7 \%$, vs. $15.6 \%$, very satisfied, respectively). The highest percentage after those mentioned above is the indifferent with $35.9 \%$ in women and $30.4 \%$ in men.

Table 1. Sociodemographic data of study participants. $n=87$.

\begin{tabular}{|c|c|c|}
\hline Sociodemographic data & Frequency & $\%$ \\
\hline \multicolumn{3}{|l|}{ Years (age) } \\
\hline $19-29$ & 36 & 31 \\
\hline $30-39$ & 22 & 25 \\
\hline $40-49$ & 22 & 25 \\
\hline $50-69$ & 12 & 14 \\
\hline Total & 87 & 100 \\
\hline \multicolumn{3}{|l|}{ Sex } \\
\hline Women & 64 & 74 \\
\hline Men & 23 & 26 \\
\hline Total & 87 & 100 \\
\hline \multicolumn{3}{|l|}{ Profession } \\
\hline Doctor & 17 & 20 \\
\hline Nurse & 21 & 24 \\
\hline Intern & 49 & 56 \\
\hline Total & 87 & 100 \\
\hline \multicolumn{3}{|l|}{ Position } \\
\hline Nursery chief & 10 & 11 \\
\hline Doctor & 21 & 24 \\
\hline Assistant or nursing technician & 11 & 11 \\
\hline General nurse & 30 & 35 \\
\hline Director or deputy director of the unit & 5 & 5 \\
\hline Others & 14 & 14 \\
\hline Total & 87 & 100 \\
\hline \multicolumn{3}{|l|}{ Academic level } \\
\hline Baccalaureate or technical & 1 & 1 \\
\hline Technician or auxiliaries & 17 & 20 \\
\hline Bachelor's degree & 62 & 71 \\
\hline Posgraduate & 7 & 8 \\
\hline Total & 87 & 100 \\
\hline
\end{tabular}

Source: Direct. 
In relation to the profession of the service provider, $23.8 \%$ of the medical staff is very satisfied and the nursing staff $16.3 \%$. The internship service provider (doctor or nurse), $11.8 \%$ said they were very satisfied. On the other hand, as regards the position of the provider, the one who has the functions of head of Nursery chiefis dissatisfied $30.0 \%$ and $50.0 \%$ satisfied. The medical staff is indifferent $28.6 \%$ and very satisfied $19.0 \%$. The staff that works as an auxiliary or nursing technician is very satisfied $10.0 \%$ and $50.0 \%$ indifferent, while the staff that performs as a general nurse is very satisfied at $20.0 \%$ and $30.0 \%$ is indifferent. As for the staff that holds a management position $50.0 \%$ is very satisfied. Regarding the academic level, $41.2 \%$ of technicians or auxiliaries are indifferent, as well as staff with a degree (29\%) and staff with some postgraduate (71.4\%) (Table 2).

Table 2. Overall satisfaction in relation to sociodemographic variables. $\mathrm{N}=87$.

\begin{tabular}{|c|c|c|c|c|c|c|c|c|c|c|}
\hline \multirow{2}{*}{$\begin{array}{c}\text { Sociodemographic } \\
\text { data }\end{array}$} & \multicolumn{2}{|c|}{ Dissatisfied } & \multicolumn{2}{|c|}{ Little satisfied } & \multicolumn{2}{|c|}{ Indifferent } & \multicolumn{2}{|c|}{ Satisfied } & \multicolumn{2}{|c|}{ Very satisfied } \\
\hline & $\mathrm{Fx}$ & $\%$ & $\mathrm{Fx}$ & $\%$ & $\mathrm{Fx}$ & $\%$ & $\mathrm{Fx}$ & $\%$ & $\mathrm{Fx}$ & $\%$ \\
\hline \multicolumn{11}{|l|}{ Years (age) } \\
\hline $19-29$ & 0 & 0 & 1 & 3.2 & 12 & 38.7 & 16 & 51.6 & 2 & 6.5 \\
\hline $30-39$ & 2 & 9.1 & 1 & 4.5 & 9 & 40.9 & 6 & 27.3 & 4 & 18.2 \\
\hline $40-49$ & 0 & 0 & 2 & 9.1 & 8 & 36.4 & 8 & 36.4 & 4 & 18.1 \\
\hline $50-59$ & 0 & 0 & 1 & 11.2 & 0 & 0 & 4 & 44.4 & 4 & 44.4 \\
\hline $60-69$ & 0 & 0 & 0 & 0 & 1 & 33.3 & 1 & 33.3 & 1 & 33.3 \\
\hline \multicolumn{11}{|l|}{ Sex } \\
\hline Women & 2 & 3.1 & 3 & 4.7 & 23 & 35.9 & 26 & 40.6 & 10 & 15.6 \\
\hline Men & 0 & 0 & 2 & 8.7 & 7 & 30.4 & 9 & 39.2 & 5 & 21.7 \\
\hline \multicolumn{11}{|l|}{ Profession } \\
\hline Doctor & 1 & 4.8 & 1 & 4.8 & 8 & 38.0 & 6 & 28.6 & 5 & 23.8 \\
\hline Nurse & 1 & 2.0 & 4 & 8.2 & 16 & 32.7 & 20 & 40.8 & 8 & 16.3 \\
\hline Intern & 0 & 0 & 0 & 0 & 6 & 35.3 & 9 & 52.9 & 2 & 11.8 \\
\hline \multicolumn{11}{|l|}{ Position } \\
\hline Nursery chief & 3 & 30.0 & 0 & 0 & 0 & 0 & 5 & 50.0 & 2 & 20.0 \\
\hline Doctor & 1 & 4.8 & 0 & 0 & 6 & 28.6 & 10 & 47.6 & 4 & 19.0 \\
\hline $\begin{array}{l}\text { Assistant or nursing } \\
\text { technician }\end{array}$ & 0 & 0 & 1 & 10.0 & 5 & 50.0 & 3 & 30.0 & 1 & 10.0 \\
\hline General nurse & 1 & 3.3 & 2 & 6.7 & 9 & 30.0 & 12 & 40.0 & 6 & 20.0 \\
\hline $\begin{array}{l}\text { Director or deputy } \\
\text { director of the unit }\end{array}$ & 0 & 0 & 1 & 25.0 & 1 & 25.0 & 0 & 0 & 2 & 50.0 \\
\hline Others & 0 & & 1 & 8.3 & 6 & 50.0 & 5 & 41.7 & 0 & 0 \\
\hline \multicolumn{11}{|l|}{ Academic level } \\
\hline Baccalaureate & 0 & 0 & 0 & 0 & 0 & 0 & 0 & 0 & 1 & 100.0 \\
\hline $\begin{array}{l}\text { Technician or } \\
\text { auxiliaries }\end{array}$ & 1 & 5.9 & 1 & 5.9 & 7 & 41.2 & 5 & 29.4 & 3 & 17.6 \\
\hline Bachelor's degree & 1 & 1.6 & 4 & 6.5 & 18 & 29.0 & 28 & 45.2 & 11 & 17.7 \\
\hline Posgraduate & 0 & 0 & 0 & 0 & 5 & 71.4 & 1 & 14.3 & 1 & 14.3 \\
\hline
\end{tabular}

Source: direct. 
In relation to the intrinsic dimension, the category with the highest percentage of satisfaction (28.8\%) is "delegation of activities", and the category with the highest percentage of dissatisfaction (20.9\%) is "professional recognition" (Table 3).

Regarding the extrinsic dimension, according to satisfaction level, the category with the highest degree of satisfaction (49.4\%) was "infrastructure and materials" and the category with the highest degree of dissatisfaction (23\%) was the "remuneration". It is observed that the staff is indifferent to the category "policies of the institution" by $28.7 \%$ (Table 4 ).

The value of all correlation coefficients are positive, indicating that while satisfaction increases in intrinsic dimensions also does in extrincical dimensions, such correlations are significant $(\mathrm{p}<0.05)$, except between Delegation of ac-tivities and Remuneration $(r=0.074$ and $\mathrm{p}=0.497)$ (Table 5).

\section{Discussion}

Regarding the socio-demographic data of this study, it was found that the age prevalence range was 19 - 29 years, similar to the study carried out by Cifuentes Rodríguez in 2012, on the working conditions and the degree of satisfaction of the Nursing professionals [9], where the participants were also young people between ages of 22 and 48 years. On the other hand, in a study carried out by Adams in 2000, it is found that at older age there is a greater dissatisfaction due

Table 3. Level of satisfaction by categories of the intrinsic dimension. $\mathrm{N}=87$.

\begin{tabular}{|c|c|c|c|c|c|c|c|c|c|c|}
\hline \multirow[t]{2}{*}{ Category } & \multicolumn{2}{|c|}{ Dissatisfied } & \multicolumn{2}{|c|}{$\begin{array}{c}\text { Little } \\
\text { satisfied }\end{array}$} & \multicolumn{2}{|c|}{ Indifferent } & \multicolumn{2}{|c|}{ Satisfied } & \multicolumn{2}{|c|}{$\begin{array}{c}\text { Very } \\
\text { satisfied }\end{array}$} \\
\hline & $\mathrm{Fx}$ & $\%$ & $\mathrm{Fx}$ & $\%$ & $\mathrm{Fx}$ & $\%$ & $\mathrm{Fx}$ & $\%$ & $\mathrm{Fx}$ & $\%$ \\
\hline Self realization & 9 & 10.4 & 19 & 21.8 & 19 & 21.8 & 23 & 26.5 & 17 & 19.5 \\
\hline Professional recognition & 17 & 20.9 & 24 & 27.9 & 25 & 28.9 & 17 & 18.0 & 4 & 4.3 \\
\hline Delegation of activities & 5 & 5.7 & 9 & 10.3 & 18 & 20.7 & 30 & 34.5 & 25 & 28.8 \\
\hline $\begin{array}{c}\text { Recognition of contributions to } \\
\text { the program }\end{array}$ & 3 & 3.4 & 16 & 18.5 & 27 & 31.0 & 26 & 29.9 & 15 & 17.2 \\
\hline
\end{tabular}

Source: direct.

Table 4. Level of satisfaction by categories of the extrinsic dimension. $\mathrm{N}=87$.

\begin{tabular}{|c|c|c|c|c|c|c|c|c|c|c|}
\hline \multirow[t]{2}{*}{ Category } & \multicolumn{2}{|c|}{ Dissatisfied } & \multicolumn{2}{|c|}{$\begin{array}{c}\text { Little } \\
\text { satisfied }\end{array}$} & \multicolumn{2}{|c|}{ Indifferent } & \multicolumn{2}{|c|}{ Satisfied } & \multicolumn{2}{|c|}{$\begin{array}{c}\text { Very } \\
\text { satisfied }\end{array}$} \\
\hline & $\mathrm{Fx}$ & $\%$ & $\mathrm{Fx}$ & $\%$ & $\mathrm{Fx}$ & $\%$ & $\mathrm{Fx}$ & $\%$ & $\mathrm{Fx}$ & $\%$ \\
\hline $\begin{array}{l}\text { Infrastructure } \\
\text { and materials }\end{array}$ & 3 & 3.4 & 6 & 6.9 & 7 & 9.2 & 24 & 31.0 & 47 & 49.4 \\
\hline Remuneration & 20 & 23.0 & 7 & 9.0 & 20 & 23.0 & 16 & 17.4 & 24 & 27.6 \\
\hline Labor relations & 2 & 2.2 & 4 & 4.6 & 16 & 18.5 & 25 & 28.7 & 40 & 46.0 \\
\hline $\begin{array}{c}\text { Institution } \\
\text { policies }\end{array}$ & 3 & 3.4 & 7 & 8.2 & 25 & 28.7 & 39 & 44.8 & 13 & 14.9 \\
\hline
\end{tabular}

Source: direct. 
Table 5. Correlation between intrinsic and extrinsic factors.

\begin{tabular}{|c|c|c|c|c|c|}
\hline \multirow{2}{*}{$\begin{array}{l}\text { Intrinsic } \\
\text { factors }\end{array}$} & \multirow{2}{*}{$\begin{array}{l}\text { Statistical } \\
\text { indicator }\end{array}$} & \multicolumn{4}{|c|}{ Extrinsic factors } \\
\hline & & $\begin{array}{l}\text { Infrastructure } \\
\text { and materials }\end{array}$ & Remuneration & $\begin{array}{l}\text { Labor } \\
\text { relations }\end{array}$ & $\begin{array}{l}\text { Institution } \\
\text { policies }\end{array}$ \\
\hline \multirow[t]{2}{*}{ Self realization } & $\begin{array}{l}\text { Correlation } \\
\text { coefficient }^{*}\end{array}$ & 0.323 & 0.214 & 0.325 & 0.454 \\
\hline & $\mathrm{p}^{*}$ & 0.002 & 0.046 & 0.002 & $<0.001$ \\
\hline \multirow{2}{*}{$\begin{array}{l}\text { Professional } \\
\text { recognition }\end{array}$} & $\begin{array}{l}\text { Correlation } \\
\text { coefficient }^{*}\end{array}$ & 0.310 & 0.211 & 0.389 & 0.411 \\
\hline & $\mathrm{p}^{*}$ & 0.003 & 0.049 & $<0.001$ & $<0.001$ \\
\hline \multirow{2}{*}{$\begin{array}{l}\text { Delegation of } \\
\text { activities }\end{array}$} & $\begin{array}{l}\text { Correlation } \\
\text { coefficient }^{*}\end{array}$ & 0.391 & 0.074 & 0.540 & 0.384 \\
\hline & $\mathrm{p}^{*}$ & $<0.001$ & 0.497 & $<0.001$ & $<0.001$ \\
\hline \multirow{2}{*}{$\begin{array}{l}\text { Recognition of } \\
\text { contributions } \\
\text { to the program }\end{array}$} & $\begin{array}{l}\text { Correlation } \\
\text { coefficient }^{*}\end{array}$ & 0.439 & 0.357 & 0.516 & 0.375 \\
\hline & $\mathrm{p}^{*}$ & $<0.001$ & $<0.001$ & $<0.001$ & $<0.001$ \\
\hline
\end{tabular}

Source: direct. ${ }^{\star}$ Linear correlation of Pearson.

to the monotony of work [10], and in the present investigation it was found that the young population reported being more dissatisfied in most categories, unlike older service providers. In this study, the male population was most satisfied, in contrast to was found in a study carried out by Carrillo and co-workers in 2013, which indicates that women show greater satisfaction than men with work or activity they perform [11].

Regarding satisfaction according to the profession performed by the service provider, it was found that physicians present a higher degree of job satisfaction in all categories, unlike what was found by Acamer-Raga and co-workers in 2009 [12]. In this study, the physicians showed a lower degree of job satisfaction, in relation to a less varied distribution of tasks and a greater burden of care. The functioning of the teams, incentives and opportunities for professional development, as well as workload and environmental conditions, were assessed negatively by this group, in front of the nursing staff.

In relation to the position held, as in the present study it was found that the bosses have the highest percentage of satisfaction. As for the academic level, the service provider with the highest degree of satisfaction is the one who holds the degree either in nursing or medicine, according to our study; in contrast we find that the staff that works as a technician or auxiliary has a lower degree of dissatisfaction. Herzberg's theory points out that intrinsic and extrinsic factors directly influence job satisfaction. According to this theory, the presence of motivating factors would lead to satisfaction and absence of non-satisfaction [13]. In the results obtained in the present study it is found that the extrinsic dimension is the one that shows greater degree of satisfaction, unlike the intrinsic dimension which shows the highest levels of job dissatisfaction. As for the intrinsic dimension which refers to self-realization, professional recognition, delegation 
of activities, supervision received and recognition of contributions to the program of Timely Detection of Cervical Cancer of Mexico was found to be mostly indifferent. In a study done in Argentina by Briseño 2005 [14], occupational satisfaction was measured in the nursing staff and it was found that the degree of dissatisfaction is $100 \%$ with respect to the salary or possibilities of promotion and $100 \%$ refer to little overall satisfaction. With regard to the relationship with bosses, superiors and the organization of work, most were little satisfied. Health personnel are satisfied with regard to the "self-actualization" category in relation to the training they receive, as well as opportunities to develop professionally in the workplace. The percentage that follows is indifferent. With regard to the category of professional recognition, the level of satisfaction of health personnel was evaluated in relation to the economic and moral stimuli granted by their superiors; it was obtained that the majority of the staff is not satisfied especially in the aspect of the economic remuneration for their services, as in the study carried out by Tapia Martínez and co-workers in 2010 [15] where it was found that the staff is not satisfied with the way in which it is supported and supervised by the immediate superiors, and in turn it alludes to the nonconformity with the perceived salary. In relation to the categories of "delegation of activities and recognition of contributions" to the program, it was obtained that the main results are: satisfied. These categories are within the intrinsic factors, that is to say the motivational factors, which, if modified, are able to increase. The two categories mentioned above include the autonomy and freedom of the personnel in relation to their work, as well as the participation that this has and the attention of superiors to their suggestions. In the present study the staff reports that there are limitations to their autonomy in relation to the work method and task planning, as well as in the strategies to be able to provide a better attention to the patients.

It was found that in some health centers where there is an exclusive module for taking cytologies, the nurses in charge referred to different strategies to carry out a more efficient control of their patients; however some of these strategies were not fully accepted by higher authorities. This indicates that there is no recognition of the significant contributions of health personnel, which is comparable with the study of Sarwar, S. and Abugre, J. (2013) [16]; the results of this study suggest that higher rewards and satisfied employees in work organizations play a major role both in the promotion of employee job satisfaction and consequently higher productivity in organizations. Thus, a significant proportion of professionals surveyed face their daily task with the perception that they have no possibility of moving up the place in their workplace. In the present study the majority of the staff is very satisfied with the category "infrastructure and materials", the above is similar to what was found in the study carried out by Solano Aguilar on job satisfaction in nursing professionals, the results show that nurses are satisfied with their work environment [17]. In the category "labor relations", those referring to how favorable or satisfactory they consider their relationship with health personnel, communication with the patient, collaboration between 
professionals, administrative support, the relationship with the immediate authorities and the equality and fairness in the treatment they receives, health personnel refers to feeling satisfied, the result with the purchase of a match with Wyatt and Harrison in 2010,where $87 \%$ of the participants considered that their job satisfaction was excellent or good. The factor most identified for job satisfaction was "interpersonal relationships with colleagues", as well as the support they receive from their work environment and the recognition they receive for their status [18]. In the present study while satisfaction increases in intrinsic dimensions also does in extrinsic dimensions, such correlations are significant, except between delegation of activities and remuneration, the majority of staff surveyed reported having no problems regarding communication and relationship with other colleagues, but they emphasized the relationship with their superiors and immediate bosses, since they consider that there is a great lack of communication. This is very important since Herzberg considers that the relationship of an individual to his work is fundamental and that his attitude toward work can determine his success or failure. In the "institution policy" category, degree of satisfaction of the personnel with regard to the regulations was taken into account; the latter refers to the legal framework of the Mexican Cervical Cancer Timely Detection program, achievements of goals and objectives of the same, as well as the system of complaints and benefits. The health staff is very satisfied, in relation to the issues mentioned above.

\section{Conclusion}

Finally, for future research it is recommended to study the factors that influence the motivation of the personnel to strengthen their training and professional development, as well as the aspects involved for the service provider to have a high satisfaction in the work.

\section{References}

[1] United States of Mexico, Ministry of Health (2006) Official Mexican Standard NOM-014-SSA2-1994, for the Prevention, Detection, Diagnosis, Treatment, Control and Epidemiological Surveillance of Uterine Cancer. Official Newspaper of the Federation.

[2] Ferlay, J., Soerjomataram, I., Dikshit, R., Eser, S., Mathers, C., Rebelo, M., Parkin, D.M., Forman, D. and Bray, F. (2015) Cancer Incidence and Mortality Worldwide: Sources, Methods and Major Patterns in GLOBOCAN 2012. International Journal of Cancer, 136, E359-E386. https://doi.org/10.1002/ijc.29210

[3] GLOBOCAN Cancer Fact Sheets: Cervical Cancer (2012). http://www.discoverymedicine.com/Lynette-Denny/2012/08/27/cervical-cancer-pre vention-and-treatment/

[4] International Agency of Research in Cancer (IARC) Cervical Cancer (2014). http://screening.iarc.fr/cervicalindex.php

[5] Ministry of Health (2008) Undersecretary of Prevention and Social Promotion. Specific Action Program 2007-2012, Cervical Cancer. United States of Mexico.

[6] Torres Lobatón, L., Rojo Herrera, G., Torres Rojo, A., Hurtado Estrada, G. and Román Bassaure, E. (2004) Cervical Cancer. Current View of Its Epidemiology and 
Risk Factors. Ginecología y Obstetricia de México, 72, 466-474.

[7] Montoya-Fuentes, H., Suárez-Rincón, A.E., Ramírez-Muñoz, M.P., Arévalo-Lagunas, I., Morán-Moguel, M.C., Gallegos-Arreola, M.P., Flores-Martínez, S.E., RosalesQuintana, S. and Sánchez-Corona, J. (2001) The Detection of Human Papillomavirus 16, 18, 35 and 58 in Cervical-Uterine Cancer and Advanced Degree of Squamous Intraepithelial Lesions in Western Mexico: Clinical-Molecular Correlation. Ginecologíay Obstetricia de México, 9, 137-142.

[8] United States of Mexico (1986) Presidency of the Republic. Regulation of the General Health Law on the Provision of Health Care Services.

[9] Cifuentes Rodríguez, J.E. and Manrique, F.G. (2014) Job Satisfaction in Nursing in a Fourth Level Attention Health Institute, Bogotá, Colombia. Revista Avances de Enfermería, 32, 217-227. https://doi.org/10.15446/av.enferm.v32n2.46207

[10] Adams, B. (2000) Hospital Nurses' Job Satisfaction, Individual and Organizational Characteristics. Journal of Advanced Nursing, 32, 563-543. https://doi.org/10.1046/j.1365-2648.2000.01513.x

[11] Carrillo-García, C., Solano-Ruíz, M.C., Martínez-Roche, M.E. and Gómez-García, C.I. (2013) Influence of Gender and Age: Job Satisfaction of Health Professionals. Revista Latino-Americana de Enfermagem, 21, 1314-1320. https://doi.org/10.1590/0104-1169.3224.2369

[12] Acámer Raga, F., López Arribas, C. and López-Torres Hidalgo, J. (1997) Work Satisfaction of Primary Care Health Professionals. Atención Primaria, 20, 401-407.

[13] García-Ramos, M., Luján-López, M. and Martínez Corona, M. (2010) Work Satisfaction of Health Personnel. Revista de Enfermeríadel IMSS, 15, 63-72.

[14] Briseño, C.E. (2005) Job Satisfaction in the Nursing Staff in the Health Sector Public. Electronic Journal of Intensive Medicine. Argentina: Especial Article, 5. http://remi.uninet.edu/2005/05/REMIA030.pdf

[15] Tapia Martínez, H., Ramírez Rodríguez, C. and Islas García, E. (2009) Job Satisfaction in Nurses of the Oncology Century XXI Hospital National Medical Center IMSS. Enfermería Universitaria, 6, 21-25. http://www.redalyc.org/articulo.oa?id=358741831004

[16] Sarwar, S. and Abugre, J. (2013) The Influence of Rewards and Job Satisfaction on Employees in the Service Industry. The Business and Management Review, 3, 23-32. http://www.abrmr.com/myfile/best_track/best_track_50317.pdf

[17] Solano-Aguilar, S. (2010) Labor Satisfaction in Nursing Professionals. Revista CUIDARTE, 1, 53-62. http://www.redalyc.org/articulo.oa?id=359533177008

[18] Wyatt, J. and Harrison, M. (2010) Certified Pediatric Nurses' Perceptions of Job Satisfaction. Paediatric Nursing, 36, 205-208. 
Submit or recommend next manuscript to SCIRP and we will provide best service for you:

Accepting pre-submission inquiries through Email, Facebook, LinkedIn, Twitter, etc. A wide selection of journals (inclusive of 9 subjects, more than 200 journals)

Providing 24-hour high-quality service

User-friendly online submission system

Fair and swift peer-review system

Efficient typesetting and proofreading procedure

Display of the result of downloads and visits, as well as the number of cited articles Maximum dissemination of your research work

Submit your manuscript at: http://papersubmission.scirp.org/

Or contact health@scirp.org 